\title{
CSOPAK ÉS KÖRNYÉKÉNEK GEOTURISZTIKAI FELMÉRÉSE
}

\author{
PÁL MÁRTON - ALBERT GÁSPÁR \\ A GEOTOURISM ASSESSMENT OF CSOPAK AND ITS SURROUNDINGS
}

\begin{abstract}
Geotourism has developed rapidly in the last decades. Geosites are the most interesting inanimate formations on Earth, and geotourism and geoheritage facilitate the preservation and popularization of their value. The processes of our planet can be well-interpreted through them. The UNESCO Global Geoparks Network is responsible for gathering, protecting, monitoring and fostering these natural values. More and more communities try to reveal geotourism attractions as they attract a wide group of people with an interest in earth sciences.

Our goal is to determine the geotourism potential in the surroundings of Csopak. The studied area is part of the Bakony-Balaton Geopark, which is a part of the UNESCO Global Geoparks Network. This work has a significant importance, as assessment models have not been applied here before.

A group of potential geosites has been designated with the help of geological and topographic maps. The fieldwork included 75 sites, and was followed by the application of the Geosite Assessment Model (GAM) and the Modified Geosite Assessment Model (M-GAM). The GAM has been applied in Hungary several times with good results. As the M-GAM takes visitors into consideration, a more realistic and practical result can be produced. The comparison of the two models also provides hints concerning the potential and possible development directions of the sites. The assessment included GIS work, an examination of geological formations and infrastructure, as well as consulting with experts.

The final score of a geosite is the sum of its scientific, educational, scenic, and infrastructural values. The final proportion of these values plotted on a matrix diagram determines the geotourism potential and the improvable elements of a geosite.

Local communities and the Bakony-Balaton UNESCO Global Geopark have to work together in order to monitor, maintain, and develop natural attractions. The results of the assessment are suitable for new strategies that deal with how geosites could be treated in the way the visitors expect it. The first geological-tourist map of the area helps to disseminate the results of the present study. It is also a didactic tool in the hands of geotourists to discover natural treasures.
\end{abstract}

Keywords: geotourism, quantitative assessment, geopark, geoheritage

\section{Bevezetés}

Napjainkban a geoturizmus, mint az idegenforgalom egyik modern ága, egyre nagyobb jelentőséggel bír, ami közvetve az elmúlt évtizedek globális információs forradalmának turizmusra gyakorolt pozitív hatásainak köszönhető (NEwsome, D.-Dowling, R. 2010). Számos tanulmány megállapításait összegezve: a geoturizmus olyan idegenforgalmi ág, amely elsősorban a földtani és tájképi értékekre fókuszál, elősegíti ezek népszerúsítését, a geodiverzitás megőrzését és a különböző földtudományok megértését. Ezt geológiai feltárások bemutatásával, vezetett túrák, kilátópontok, illetve látogatóközpontok segítségével éri el. Fontos szereplői azonban a kulturális, bányászati és építészeti örökség helyszínei is, amelyek az ember természettel való kapcsolatához köthetó értékeket mutatják be (pl. Hose, T. A. 1996; Newsome, D.-Dowling, R. 2010; Birlha et al. 2018).

A földtudományi értékek geotópok (geo-objektumok, geohelyszínek, geosite-ok) formájában mutathatók be, hiszen az élettelen környezet leglátványosabb, legjellegzetesebb, legérdekesebb helyszíneit, formakincsét jelentik meg (pl. Hose, T. A. 1996; STUEve, A. 
M. et al. 2002; BriLha, J. 2015; BirlHA, J. et al. 2018; SzEPESI J. et al. 2018). Ezek a képződmények különféle természeti alakzatok lehetnek: sziklafalak, barlangok, feltárások, illetve maga a táj is. Vizsgálatuk és megfigyelésük során betekintést nyerhetünk a földtörténeti múlt egy időszakába. A geohelyszínek meghatározásához elsősorban tudományos szempontok szükségesek (pl. a képződmények ritkasága), de az objektum bemutathatósága és szemléletessége is fontos tényező (l. korábbi hivatkozások, továbbá: Magyarhoni Földtani Társulat, 2017).

A geohelyszínek mint turisztikai desztinációk, a geológiai örökség bemutatásán (geointerpretáció) keresztül a látogatók körében elégedettséget generálnak. A helyi lakosok számára ez nem csak bevételi forrást jelenthet, hanem szemléletformálást is, hiszen identitástudatuk részévé válnak a földtani értékek. A bemutatott helyszíneket bárki felkeresheti a földtani értékeket kevésbé értó és becsülő látogatók, valamint akár képzett földtudósok is (GRANT, C. 2010; Dowling, R. 2011).

A geoturizmus a természeti környezettel kapcsolatos kulturális és természeti értékek iránti érzékenységet, érdeklődést is jelenti. Az élményszerú időtöltés mellett fontos a környezetbarát szemlélet is: a geoturista a saját ismereteinek elmélyítése mellett hangsúlyt fektet a természet megóvására is. A geointerpretáció alkalmat ad a helyiek és a turisták tudományos nevelésére földtani ismeretek átadása révén (REYNARD, E. 2008). Mivel létrejöttéhez szükséges bizonyos infrastruktúra, munkahelyteremtő és gazdaságélénkítő szerepe is jelentős lehet (DowLING, R. 2011).

A geoparkok szervezett keretek között adnak teret a geoturizmusnak. Az élettelen természeti képződmények nemzetközi védelme az Európai Geopark Hálózat (European Geoparks Network, EGN) és a UNESCO Globális Geopark Hálózat (Global Geoparks Network, GGN) megalakulásával szervezetté vált. Sok helyen szemponttá vált a fenntartható természetközeli turisztikai lehetőségek népszerúsítése. A földtani örökség bemutatásán túl a parkok kulturális, történelmi és ökológiai értékeket is hordoznak, illetve szervesen kapcsolódnak a környezeti oktatásba, nevelésbe és a tudományos kutatásokba. E szempontok figyelembevételével tehát megállapítható, hogy egy geopark jelentős társadalmi, környezetvédelmi és gazdasági potenciált hordoz. Ennek elemei a helyi kézmúves termékek, élelmiszerek terjesztése, kulturális programok népszerűsítése (GÁLOSI K. B.-HoRvÁTH G. 2018; Bakony-Balaton Geopark, 2012).

A bemutatásra szánt helyszínek sok esetben generációk óta ismert, látványos képződmények (pl. barlangok, szurdokvölgyek), de gyakori, hogy egy felhagyott kőfejtő, vagy egy útépítés során létrejövő szikla válik geohelyszínné. A helyszínek kiválasztása a BakonyBalaton Geopark 2012. évi létrejöttekor a területet jól ismerő szakértők feladata volt, azonban az azóta eltelt időszak során világosan látható az a tendencia, hogy objektivitásra törekvő mennyiségi (kvantitatív) értékelés eredménye alapján kerüljenek kiválasztásra a helyszínek. Ennek oka elsősorban a gyarapodó globális geopark-hálózat, ami a globális szintű összevethetőséget is igényként támasztja. Az idegenforgalmi szempontból hasznosítható geotópok kvantitatív módszerekkel történő feldolgozását és értékelését geoturisztikai potenciálbecslésnek nevezzük.

\section{Célkitưzés}

A geotudományos szempontból jelentős természeti, valamint tájértékek jóval kevésbé ismertek, mint a mesterséges környezet értékei. Ennek oka legtöbbször az, hogy a felvételezők sem ismerik fel a jelentőségüket (TóTH Sz. et al. 2015). Magyarországi földtani szempontból jelentős turisztikai célterületre már több ízben alkalmaztak kvantitatív értékelési 
módszereket. Fejér megyei mintaterületen történt vizsgálat során a Velencei-hegységben 13, a Keleti-Bakonyban pedig 8, adottságaik alapján fejleszthető helyszínt eredményezett a felmérés (CsoRvÁsi N. 2017). A Tokaj-hegyaljai történelmi borvidék vulkanológiai látványosságai is kvantitatív módon kerültek felmérésre (SZEPESI, J. et al. 2016). Ennek célja olyan turisztikai szempontból hasznosítható geotópok felkutatása, amelyek a jövőben megalapozhatják a tervezett Pannon Vulkán út létrejöttét.

Kutatásunk célja olyan földtani objektumok keresése a Bakony-Balaton Geopark kijelölt területén, amelyek rendelkeznek geoturisztikai fejlesztésekhez elegendő potenciállal. Ez segíti a Balaton-felvidék K-i részén található geológiai értékek bemutatását, egyszersmind védelmét is. A feldolgozott és számértékekkel jellemezhetô, felmért geotópok gazdaságilag kedvezóek a helyiek számára a turisztikai vonzerejükre épített infrastruktúra révén, illetve alapját képezhetik egyéb fejlesztéseknek, természetvédelmi munkáknak. A vizsgált területen kvantitatív módszerrel meghatározott geopotenciál-értékek továbbá fontos összehasonlítási alapot adhatnak a korábban csak szubjektív módszerrel kijelölt helyszínek globális skálán történő elhelyezéséhez.

\section{A vizsgált terület kijelölése}

A vizsgált területet az ÉK-i és DNy-i oldalon Balatonalmádi és Balatonfüred, ÉNy-on Veszprémfajsz és Hidegkút É-i határa, DK-en a Balaton határolja (1.ábra).

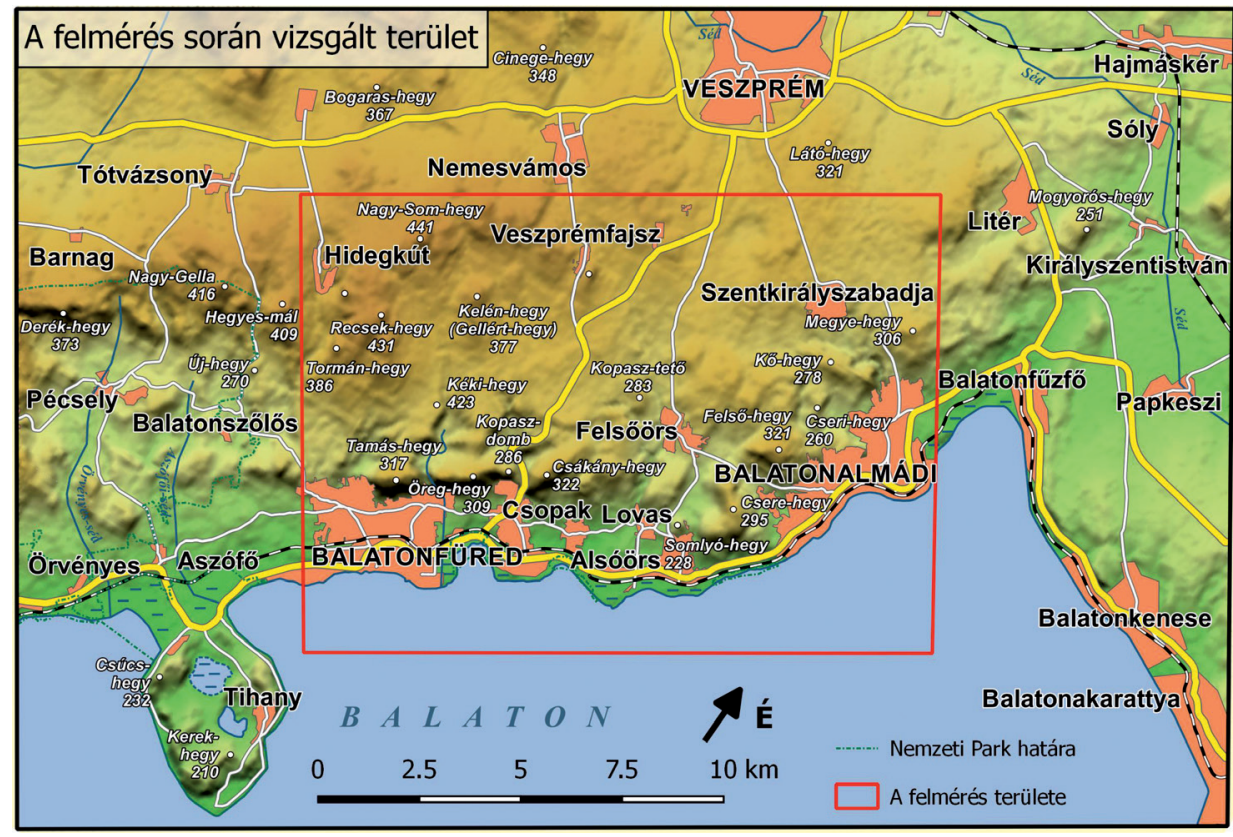

1. ábra A vizsgált terület és környékének térképvázlata

Figure 1 Map of the research area

A területről készült viszonylag nagy méretarányú turistatérkép (SCHWARCZ Gy. 2013) a természetes és kulturális látványosságokat egyaránt nagy részletességgel mutatja be. Ez alkalmassá teszi arra, hogy térképi alapként szolgáljon egy földtani túratérképhez, amely- 
nek múfaját AlBert G. (2004) ismertette. E földtani túratérkép a Geoparkkal együttmúködve készült (ALBERT G. et al. 2018), és az ehhez használt térképi alap a turistatérképről átvett tartalmat földtani tematikával kiegészítve használja. E kutatás ehhez a térképmúhöz is segítséget nyújtott: a felmért geotópok kerültek térképi ábrázolásra, a legjobb értékelést kapó helyszínekről pedig szöveges ismertető is készült. E párhuzamos munka indokolta a szabályos alakú területhatárolást.

\section{A vizsgálati módszer áttekintése}

A turisztikai potenciál fogalma az elmúlt évtizedek során folyamatosan fejlődött, és máig sincs egyértelmúen definiálva. A nemzetközileg ismert alapmúvekben (JAFARI, J. 2000; HALL, C.-PAGE, S. 2002) a kínálat és a turisztikai lehetőség fogalmak állnak hozzá közel. AlAVI, J.-YASIN, M. (2000) már matematikai-statisztikai módszereket használ Irán egy régiójának turisztikai jellemzéséhez. Ezt a következő években kiegészítik a jövőbeli sikerek prognózisával és a fejlesztés lehetőségeinek vizsgálatával (LAI, L.-GRAEFE, A. 2000). A definíció fejlődése a hazai szakirodalomban is hasonlóan történt és hasonló tartalmat is hordoz (GóczÁn, L.-KERTÉSZ, Á. 1988; MiChALKó G. 2005). A fogalom így már jól átültethető a geoturizmus témakörébe. Jelen tanulmányban az idegenforgalmi szempontból hasznosítható geotópok feldolgozását és értékelését értjük geoturisztikai potenciálbecslésen, aminek során mérőszámokkal meghatározott értékek alapján számolható ki egy helyszín potenciálértéke. Az arra érdemes helyszínek a későbbiekben a geoturisztikai fejlesztések középpontjában állhatnak (BRILHA, J. 2018).

\section{A GAM és M-GAM módszer bemutatása}

A Gesoite Assessment Model (GAM, Vujičić, M. et al. 2011) a kvantitatív értékelési rendszerek fejlődésének egyik sarokpontja. A már említett hazai geoturisztikai felmérések (SZEPESI, J. et al. 2016; CSORVÁSI N. 2017) - sokszínú szempontrendszere miatt - ezt a modellt tartották a leginkább reális eredményre vezetônek. Két fó részre oszlik: fó értékek (Main Values, MV) és hozzáadott értékek (Additional Values, AV). A fó értékeken belül tudományos-oktatási (scientificleducational, VSE), esztétikai (scenic/aesthetic, VSA) és természetvédelmi (protection, $V P r$ ), a hozzáadott értékeken belül infrastrukturális (functional, VFn) és turisztikai (tourism, VTr) alcsoportokat különböztetünk meg (1-2. táblázat). A fő részeken belül $12 \mathrm{MV}$, illetve $15 \mathrm{AV}$ paraméter található. A geohelyszínek ezekre a paraméterekre kapnak pontszámot, ezek 0, 0,25, 0,5, 0,75 és 1 lehetnek. Az összpontszám kiszámításához használt három egyszerú egyenlet:

$$
\begin{aligned}
M V & =V S E+V S A+V P r, \\
A V & =V F n+V T r, \\
G A M & =M V+A V .
\end{aligned}
$$

A kapott pontszámok az egyes geotópok GAM által meghatározott értékei. A pontozás részletes leírása az 1. és 2. táblázatban látható.

Kutatásunk során a Geosite Assessment Model (GAM) egy módosított változatát használjuk, amelyet hazánkban eddig még nem alkalmaztak. ToMıć, N.Božıć, S. (2014) alapvetően Vujıčıć, M. et al. (2011) módszertanát alkalmazza, azonban a GAM-ban kizárólagosan érvényesülő szakértői szempontokat kiegészítik a turisták és látogatók véleményével. Munkájuk célja így egy, a látogatók véleményét jobban tükröző módszer létrehozása volt. 
A GAM és az $M-G A M$ esetén megegyező elsődleges értékeket meghatározó paraméterek és pontozásuk, valamint az Im tényezó értékei

The Im values of the Main Value $(M V)$ indicators of GAM and M-GAM

\begin{tabular}{|c|c|c|c|c|c|c|}
\hline $\begin{array}{l}\text { Paraméterek / } \\
\text { Pontszámok: }\end{array}$ & Im & $\mathbf{0}$ & 0,25 & 0,5 & 0,75 & 1 \\
\hline \multicolumn{7}{|c|}{ Tudományos/oktatási értékek (Scientific/Educational values - VSE) } \\
\hline $\begin{array}{l}\text { Ritkaság, kör- } \\
\text { nyékbeli } \\
\text { elófordulás (db) } \\
\text { - SIMV1 }\end{array}$ & 0,95 & Gyakori & Regionális & Nemzeti & Nemzetközi & $\begin{array}{l}\text { Egyedüli } \\
\text { elófordulás }\end{array}$ \\
\hline $\begin{array}{l}\text { Képződmény } \\
\text { reprezentativi- } \\
\text { tása-SIMV2 }\end{array}$ & $\mathbf{0 , 7}$ & Nincs & Alacsony & Közepes & Magas & Kiváló \\
\hline $\begin{array}{l}\text { Geotudományos } \\
\text { publikáltság } \\
\text { - SIMV3 }\end{array}$ & 0,66 & Nincs & Helyi & Regionális & Országos & Nemzetközi \\
\hline $\begin{array}{l}\text { Szemléletesség, } \\
\text { értelmezhetőség } \\
\text { - SIMV4 }\end{array}$ & 0,84 & Nincs & $\begin{array}{l}\text { Közepesen } \\
\text { jó példa, } \\
\text { amit nehéz } \\
\text { megértetni }\end{array}$ & $\begin{array}{l}\text { Jó példa, } \\
\text { amit nehéz } \\
\text { megértetni }\end{array}$ & $\begin{array}{l}\text { Közepesen } \\
\text { jó példa, } \\
\text { amit könnyú } \\
\text { megértetni }\end{array}$ & $\begin{array}{l}\text { Jó példa, } \\
\text { amit könnyuu } \\
\text { megértetni }\end{array}$ \\
\hline \multicolumn{7}{|c|}{ Esztétikai értékek (Scenic/Aesthetic values - VSA) } \\
\hline $\begin{array}{l}\text { Rálátási pontok } \\
\text { a geosite-ra } \\
\text { - SIMV5 }\end{array}$ & $\mathbf{0 , 8 3}$ & 1 & $2-3$ & $4-6$ & 6-nál több & 1 \\
\hline $\begin{array}{l}\text { Geosite területe } \\
\text { - SIMV6 }\end{array}$ & $\mathbf{0 , 5 8}$ & Kicsi & $\mathrm{x}$ & Közepes & $\mathrm{x}$ & Nagy \\
\hline $\begin{array}{l}\text { Környezó tájké- } \\
\text { pi és természeti } \\
\text { elemek - SIMV7 }\end{array}$ & 0,91 & Alacsony & Közepes & Magas & Kiváló & Alacsony \\
\hline $\begin{array}{l}\text { Környezeti } \\
\text { illeszkedés } \\
\text { - SIMV8 }\end{array}$ & $\mathbf{0 , 8 7}$ & $\begin{array}{l}\text { Nem } \\
\text { illeszkedik }\end{array}$ & $\mathrm{x}$ & Semleges & $\mathrm{x}$ & $\begin{array}{c}\text { Jól } \\
\text { illeszkedik }\end{array}$ \\
\hline \multicolumn{7}{|c|}{ Természetvédelem (Protection values - VPr) } \\
\hline $\begin{array}{l}\text { Jelenlegi állapot } \\
\text { - SIMV9 }\end{array}$ & 0,92 & $\begin{array}{l}\text { Súlyosan } \\
\text { sérüllt } \\
\text { (természeti } \\
\text { hatások } \\
\text { miatt) }\end{array}$ & $\begin{array}{l}\text { Közepesen sé- } \\
\text { rült (fontosabb } \\
\text { geomorfológiai } \\
\text { tulajdonságok } \\
\text { megőrződtek) }\end{array}$ & $\begin{array}{l}\text { Némileg } \\
\text { sérültt }\end{array}$ & $\begin{array}{l}\text { Nem } \\
\text { sérült }\end{array}$ & $\begin{array}{l}\text { Súlyosan } \\
\text { sérült } \\
\text { (természeti } \\
\text { hatások } \\
\text { miatt) }\end{array}$ \\
\hline $\begin{array}{l}\text { Védelmi szint } \\
\text { - SIMV10 }\end{array}$ & $\mathbf{0 , 7 8}$ & Helyi & Regionális & Országos & Nemzetközi & Helyi \\
\hline $\begin{array}{l}\text { Sérülékenység } \\
\text {-SIMV11 }\end{array}$ & $\mathbf{0 , 8 7}$ & $\begin{array}{l}\text { Magas } \\
\text { (könnyen } \\
\text { rongálható) }\end{array}$ & $\begin{array}{l}\text { Közepes } \\
\text { (természeti és } \\
\text { emberi folya- } \\
\text { matok egyaránt } \\
\text { rongálhatják) }\end{array}$ & $\begin{array}{l}\text { Alacsony } \\
\text { (csak emberi } \\
\text { beavatkozás } \\
\text { rongálhatja) }\end{array}$ & $\begin{array}{l}\text { Nem } \\
\text { sérülékeny }\end{array}$ & $\begin{array}{l}\text { Magas } \\
\text { (könnyen } \\
\text { rongálható) }\end{array}$ \\
\hline $\begin{array}{l}\text { Optimális } \\
\text { látogatószám } \\
\text {-SIMV12 }\end{array}$ & $\mathbf{0 , 5 8}$ & $0-10$ & $10-20$ & $20-50$ & 50-nél több & $0-10$ \\
\hline
\end{tabular}


2. táblázat - Table 2

A GAM és az $M$-GAM esetén megegyező kiegészítő értékeket meghatározó paraméterek és pontozásuk, valamint az Im tényezó értékei

The Im values of the Additional Value $(A V)$ indicators of $G A M$ and $M-G A M$

\begin{tabular}{|c|c|c|c|c|c|c|}
\hline $\begin{array}{l}\text { Indikátorok / } \\
\text { Pontszámok: }\end{array}$ & Im & $\mathbf{0}$ & 0,25 & 0,5 & $\mathbf{0 , 7 5}$ & 1 \\
\hline \multicolumn{7}{|c|}{ Infrastrukturális érték (Functional values - VFn) } \\
\hline $\begin{array}{l}\text { Megközelíthetóség } \\
\text { - SIAV1 }\end{array}$ & $\mathbf{0 , 7 5}$ & $\begin{array}{l}\text { Megköze- } \\
\text { líthetetlen }\end{array}$ & $\begin{array}{c}\text { Rossz } \\
\text { (gyalog spe- } \\
\text { ciális eszkö- } \\
\text { zökkel, szak- } \\
\text { vezetéssel) }\end{array}$ & $\begin{array}{l}\text { Közepes } \\
\text { (kerékpárral } \\
\text { vagy egyéb } \\
\text { ember hajtotta } \\
\text { eszközzel) }\end{array}$ & $\begin{array}{l}\text { Magas } \\
\text { (autóval) }\end{array}$ & $\begin{array}{l}\text { Kiváló } \\
\text { (busszal, } \\
\text { tömegközle- } \\
\text { kedéssel) }\end{array}$ \\
\hline $\begin{array}{l}\text { Környékbeli termé- } \\
\text { szeti értékek - SIAV2 }\end{array}$ & 0,66 & Nincs & 1 & $2-3$ & $4-6$ & 6-nál több \\
\hline $\begin{array}{l}\text { Környékbeli épített } \\
\text { (történeti) értékek } \\
\text { - SIAV3 }\end{array}$ & 0,67 & Nincs & 1 & $2-3$ & $4-6$ & 6-nál több \\
\hline $\begin{array}{l}\text { Potenciális látogatók } \\
\text { lakóhelyének } \\
\text { közelsége - SIAV4 }\end{array}$ & $\mathbf{0 , 7 1}$ & $\begin{array}{l}\text { Több, mint } \\
100 \mathrm{~km}\end{array}$ & $100-50 \mathrm{~km}$ & $50-25 \mathrm{~km}$ & $25-5 \mathrm{~km}$ & $\begin{array}{l}\text { Kevesebb, } \\
\text { mint } 5 \mathrm{~km}\end{array}$ \\
\hline $\begin{array}{l}\text { Utak közelsége } \\
\text { - SIAV5 }\end{array}$ & 0,74 & Nincs & Helyi & Regionális & Országos & Nemzetközi \\
\hline $\begin{array}{l}\text { Elérthetó pontszerú } \\
\text { közlekedési infra- } \\
\text { struktúra - SIAV6 }\end{array}$ & 0,69 & Nincs & Alacsony & Közepes & Magas & Kiváló \\
\hline \multicolumn{7}{|c|}{ Turisztikai értékek (Touristic values - VTr) } \\
\hline $\begin{array}{l}\text { Népszerúsítés szintje } \\
\text { - SIAV7 }\end{array}$ & 0,71 & Nincs & Helyi & Regionális & Országos & Nemzetközi \\
\hline $\begin{array}{l}\text { Szervezett túrák } \\
\text { száma - SIAV8 }\end{array}$ & 0,56 & Nincs & $\begin{array}{l}\text { Évi 12-nél } \\
\text { kevesebb }\end{array}$ & 12-24/év & 24-48/év & $\begin{array}{l}\text { Évi 48-nál } \\
\text { több }\end{array}$ \\
\hline $\begin{array}{l}\text { Látogatóközpont } \\
\text { közelsége - SIAV9 }\end{array}$ & 0,74 & $\begin{array}{l}\text { Több, mint } \\
50 \mathrm{~km}\end{array}$ & $50-20 \mathrm{~km}$ & $20-5 \mathrm{~km}$ & $5-1 \mathrm{~km}$ & $\begin{array}{l}\text { Kevesebb, } \\
\text { mint } 1 \mathrm{~km}\end{array}$ \\
\hline $\begin{array}{l}\text { Magyarázó táblák } \\
\text { - SIAV10 }\end{array}$ & 0,87 & Nincs & $\begin{array}{l}\text { Alacsony } \\
\text { minőség }\end{array}$ & $\begin{array}{l}\text { Közepes } \\
\text { minőség }\end{array}$ & $\begin{array}{c}\text { Jó } \\
\text { minőség }\end{array}$ & $\begin{array}{l}\text { Kiváló } \\
\text { minőség }\end{array}$ \\
\hline $\begin{array}{l}\text { Látogatószám } \\
\text { - SIAV11 }\end{array}$ & 0,58 & Nincs & $\begin{array}{l}\text { Alacsony } \\
\text { (5000-nél } \\
\text { kevesebb) }\end{array}$ & $\begin{array}{c}\text { Közepes } \\
(5001-10000)\end{array}$ & $\begin{array}{l}\text { Magas } \\
(10001- \\
100000)\end{array}$ & $\begin{array}{l}\text { Nagyon ma- } \\
\text { gas (100000 } \\
\text { fölött) }\end{array}$ \\
\hline $\begin{array}{l}\text { Turisztikai infra- } \\
\text { struktúra - SIAV12 }\end{array}$ & 0,7 & Nincs & Alacsony & Közepes & Magas & Kiváló \\
\hline $\begin{array}{l}\text { Túravezetôi szol- } \\
\text { gáltatás - SIAV13 }\end{array}$ & 0,74 & Nincs & Alacsony & Közepes & Magas & Kiváló \\
\hline $\begin{array}{l}\text { Szállás közelsége } \\
\text { - SIAV14 }\end{array}$ & 0,73 & $\begin{array}{l}\text { Több, mint } \\
50 \mathrm{~km}\end{array}$ & $25-50 \mathrm{~km}$ & $10-25 \mathrm{~km}$ & $5-10 \mathrm{~km}$ & $\begin{array}{l}\text { Kevesebb, } \\
\text { mint } 5 \mathrm{~km}\end{array}$ \\
\hline
\end{tabular}

A GAM-módszer módosítására a következő paraméterek miatt került sor. Egy geotóp többféle értéket foglalhat magába, vagy közvetlen környezetében különböző lehetőségeket találhatunk, így a kulturális, történeti, tájképi, tudományos, szórakoztató, pszichológiai és múvészeti jegyeket szintén figyelembe kell vennünk. Ez javarészt abban gyökerezik, hogy 
az átlagos (geo)turista nem csak a földtani érték miatt látogat meg egy helyszínt, hanem az előbbiekben felsorolt paraméterek összessége miatt is. A magasabb fokú objektivitás elérése érdekében a tanulmány kidolgozói egy tesztet töltettek ki 96 turistával (nem földtudós, a területet nem biztos, hogy ismerő felnőtt), akik az alcsoportokon belüli paraméterek fontosságát osztályozták 0 és 1 közötti értékekkel (hasonlóan a paraméterek pontszámaihoz). Minden paraméternél az összes vélemény átlaga adja az Im (Importance) faktort mint súlytényezőt, amivel a $G A M$ által nyert pontszámokat megszorozva kapjuk a $M$-GAM értékeit:

$$
M-G A M=\operatorname{Im}(G A M)=\operatorname{Im}(M V+A V) .
$$

A módszer használatával tehát a tudományos szempontok mellett szerepet kapott az átlagos turista szemszöge is (Tomić, N.-Božıć, S. 2014).

Az $M-G A M$ eredeti leírása magában hordozza a mátrixok segítségével történő értékelés lehetőségét. Figyelembe véve, hogy melyik helyszín melyik mátrixmezőbe esik, a pontszámok alapján megállapítható geoturisztikai fejlettsége. Tomić, N. és Božıć, S. ezt a két modell közti pontértékek különbségének a szemléltetésére használta (2.ábra).
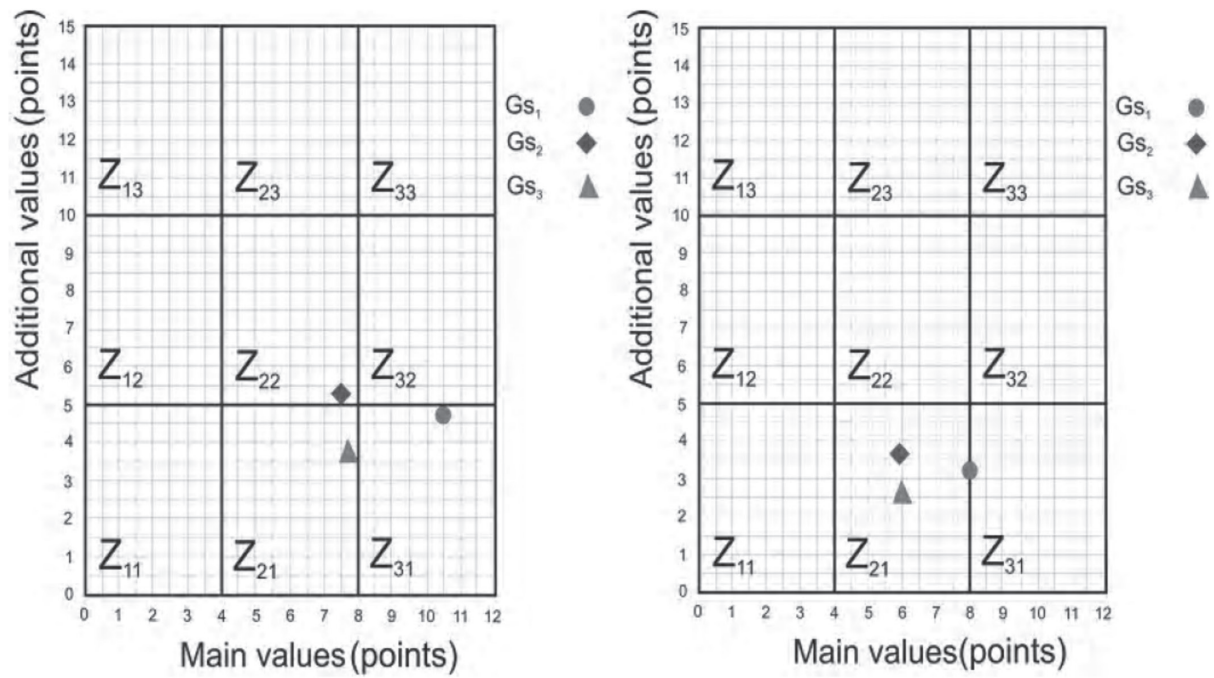

2. ábra A mátrixok alkalmazása Toмıć, N.-Božić, S. (2004). A bal oldali mátrixban a GAM, a jobb oldaliban pedig az $M-G A M$ pontszámokat ábrázolták

Figure 2 Matrixes in Tomić, N.-Božıć, S. (2004). GAM values are in the left, $M$ - GAM values are in the right matrix

Azonban ha a két modell pontszámait egy mátrixban ábrázoljuk, láthatóvá válik, hogy a geotópok mennyire igényelnek jövőbeli fejlesztést. Például míg a fenti mátrixpárban található $G S_{1}$ pont bír a legmagasabb fóérték-ponttal, a hozzáadott értékek pontszáma csak a második. Így a jövőben inkább a turisztikai infrastruktúrát célzó beruházások előnyösek. Az eredmények értékelésénél ezt a módszert használtuk.

\section{Adatfeldolgozás}

A kutatáshoz kapcsolódó adatfeldolgozás két fő munkafázisból állt: a geotópok helyének azonosítása, és az elsődleges és a másodlagos értékek meghatározása. Előbbihez elsôsorban térképi alapanyagokat használtunk; az utóbbihoz tartozott a terepi ellenőrzés, 
szakirodalmi forráselemzés, szakmai konzultáció a területet ismerő szakemberekkel, és a térinformatikai elemzés.

\section{Fö adatforrások}

A munka térképi alapját a Felsőörs és környéke c. turistatérkép (ScHWARCZ GY. 2013) határozta meg. Erről is gyújtöttünk feldolgozandó geotópokat: bizonyos térképjelek által jelölt helyszínek (sziklák, letörések, szurdokvölgyek) felkerültek a terepen ellenőrzendő pontok listájára.

A földtani adatforrások feldolgozása ezzel párhuzamosan zajlott, aminek során a legtöbb potenciális geohelyszínt gyújtöttük. Papíralapú adatforrásként A Balaton építésföldtani térképsorozatának a területre vonatkozó 1:20000-es méretarányú szelvényeit (MÁFI, 1980) és A Balaton-felvidék földtani térképét használtuk (BUDAI T. et al. 1999).

Online forrásként az MBFSZ interneten elérhető földtani alapszelvény-listáját használtuk, amelyről az összes területre eső alapszelvényt kigyűjtöttük. Továbbá a Google Earth programban rendelkezésre álló fotók, múholdképek és az OpenStreetMap hasznosítható topográfiai tartalma (felhagyott bányák, információs táblák, tanösvények, kilátópontok) is segítették a lehetséges geotópok listájának bővítését.

Az adatgyújtés végén 421 helyszín alkotta a listát. Ezt a számot a következő lépés során előzetes szűréssel csökkentettük.

\section{Az adatok elózetes szürése}

Az 1:20 000-es méretarányú építésföldtani szelvényeken minden természetes és mesterséges feltárás helye és mérete leolvasható volt. Mivel a szelvények több mint 30 éve készültek, a területen azóta lényeges változások történtek a jelölt feltárások rovására. Kevesebb kibúvás felvétele érdekében csak az 50 méternél nagyobbakat szűrtük ki. Az így előállt halmazból kivettük a beépített területre eső elemeket is.

Az MBFSZ alapszelvényeit, szakmai jelentőségük miatt, szúrés nélkül átvettük. A Google Earth (Picasa) fényképei esetenként nem megfelelő helyre voltak tűzve, illetve bizonyos helyszíneken több felvétel is készült. Ahol lehetséges volt, javítottuk és figyelembe vettük ezeket a tényezóket.

Az online módszerek használatával az előző lépések során ejtett hibák is kiküszöbölhetôk voltak. Néhány esetben ugyanis előfordult, hogy kicsi és/vagy beépített területen levő feltárások megőrződtek (pl. Alsóörsi Metariolit alapszelvény). A hatósági engedéllyel rendelkező bányatelkek magántulajdonnak minősülnek, emiatt semmilyen geoturisztikai célra nem használhatók. A Magyar Bányászati és Földtani Hivatal honlapjáról letölthető nyilvántartás segítségével 3 ilyen helyszínt zártunk ki. Így a terepi munka előtt 216 lehetséges geotóp maradt a listán (34 Picasa-fotó és 182 egyéb térképi forrásból).

\section{Terepmunka és helyszini értékelés}

A terepmunka három szakaszban (2017. augusztus 29-30., szeptember 4-6. és október 5-6.) zajlott. Az építésföldtani anyagból átvett geotóp-jelölteket 3 kategóriára osztottuk méretük (bármely irányú szélességük) szerint: 50 m, 50-100 m, 100 m-nél nagyobb. Részben a méret és az elhelyezkedés, valamint a geológiai képződmény ritkasága alapján három fontossági kategóriát (fontos, közepesen fontos, kevésbé fontos) határoztunk meg, amit már a terepbejárás tervezésekor felhasználtunk: az első két csoport jelöltjeit figyelembe véve terveztük meg utunkat. Így kiszűrődtek azok a kevésbé jelentős hely- 
színek, amelyek túraútvonalaktól távol és nehezen megközelíthetô részen helyezkednek el, ami miatt turisztikai funkciójuk minimális. Meglátogattunk minden alapszelvényt és turistatérképen jelölt sziklaalakzatot, valamint a Picasa-fényképek segítségével leolvasott objektumot. Minden feltárásnál följegyeztük a képződmény földtani besorolását, fotókat készítettünk, valamint 1-3-ig terjedő skálán a terepen is jellemeztük fontosságukat (1 - kevésbé fontos, 3 - nagyon fontos).

\section{GIS alapú értékelés}

A Modified Geosite Assessment Model $(M-G A M)$ szerinti osztályozás többféle módszer alkalmazásával végezhetô el: távolságok mérésével, képződmények legyüjtésével, gyakoriságuk vizsgálatával, pufferzónák képzésével. Ehhez a QGIS 2.18-as verziószámú szabad felhasználású szoftvert használtunk, elsősorban a feltárásoktól való távolságok alapján pontozható paraméterek értékelésekor. Az ezekkel a módszerekkel értékelt paraméterek például: SIMV1 (Ritkaság, környékbeli elöfordulás), SIAV1 (Megközelíthetöség), SIAV3 (Környékbeli épített [történeti] értékek), SIAV9 (Látogatóközpontok közelsége), SIAV14 (Szállás közelsége).

\section{Fotó- és jegyzetalapú értékelés}

A következő paramétercsoport értékeléséhez a terepi munka során készített fotók és jegyzetek nyújtottak segítséget. A SIMV2 (Képzódmény reprezentativitása) és a SIMV4 (Szemléletesség, értelmezhetöség), SIMV6 (Geotóp területe), SIMV7 (Környezó tájképi és természeti elemek), SIMV8 (Környezeti illeszkedés), SIMV9 (Jelenlegi állapot) és SIAV10 (Magyarázó táblák) esetében különösen nehéz volt az objektivitásra törekvés. Ebben a szakirodalom (BUDAI T.-KONRÁD GY. 2011; FUTÓ J. 2013), a terepi jegyzetek és fényképek segítettek. A SIMV11 (Sérülékenység) és SIMV10 (Optimális látogatószám) csoportok pontozása volt a legvégső munkafolyamat, ugyanis ezekhez a már megadott Természetvédelmi (VPr) értékeket vettük figyelembe az eddig használt anyagokon kívül.

\section{Szakértók megkeresése}

A SIMV3 (Geotudományos publikáltság), SIAV7 (Népszerüsítés szintje), SIAV8 (Szervezett túrák száma), SIAV11 (Látogatószám) és SIAV13 (Túravezetói szolgáltatás) paraméterek esetében minden geohelyszínre olyan értékek a jellemzők, amelyeket az adott helyszín tudományos vagy turisztikai adottságait jól ismerő szakemberek tudnak legjobban megbecsülni. A Geotudományos publikáltság meghatározása az ismertebb helyszínek esetében szakirodalom alapján, a kevésbé ismertek esetében BuDAI T. egyetemi tanár, a Balaton-felvidék térképezó geológusának segítségével történt, míg a többi felsorolt paraméter értékelésében KorBéLY B., a Bakony-Balaton Geopark Csoport vezetője segített.

\section{Eredmények}

A helyszínek pontszámának összegzésével elóállt a $G A M$-modell szerint számított érték. Ezt a látogatók pontozása szerint megállapított Im tényezővel szorozva megkapjuk az $M-G A M$ által adott végeredményt.

A geotópok jobb differenciálhatósága érdekében az M-GAM mátrix alkalmazása indokolt, mivel a mátrix-cellák fejlettségi kategóriákat határoznak meg. Ehhez az összesített 
eredményeket egy olyan mátrix-diagramban ábrázoltuk, ahol a vízszintes tengelyen az fó értékek $(M V)$, a függóleges tengelyen pedig a hozzáadott értékek $(A V)$ találhatók. $\mathrm{Az}$ $M-G A M$ mátrix elóállításához mindkét tengelyt az értéktartományban harmadoltuk, ami a szintén 3×3-as osztású GAM mátrixhoz hasonló, és amelynek mezői a geoturizmus jellegére és fejlettségi fokára vonatkozó minőséget hordoznak (3.ábra).

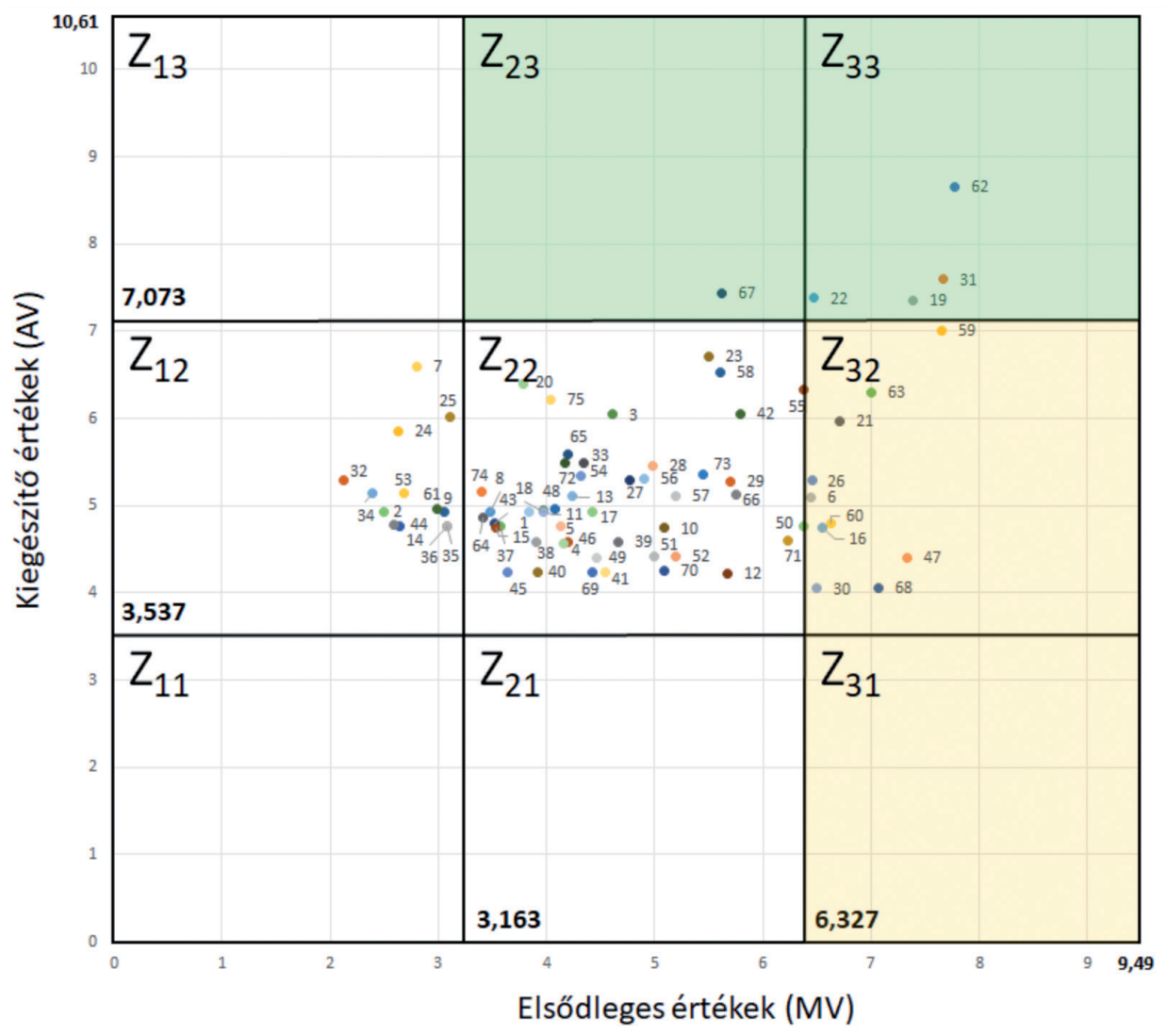

3. ábra A $M$-GAM módszer pontszámainak ábrázolása mátrixban

Figure $3 M-G A M$ values of the geosites plotted in a matrix

Az értékek bemutatását ilyen módon, míg a fejleszthetőséget $G A M$ mátrixban ábrázoljuk. Utóbbiban lehetőség nyílt a $G A M$ és $M-G A M$ pontszámok közti értékkülönbségek vizsgálatára.

$\mathrm{A} \mathrm{Z}_{23}$ és a $\mathrm{Z}_{33}$ cellákban (zölddel kiemelve) azok a helyszínek találhatók, amelyek elegendő tudományos értékkel bírnak, és jelenleg is folyik turisztikai hasznosításuk. Itt elsősorban a geoturizmus környezetre és társadalomra gyakorolt hatásait figyelembe véve kell a fenntartható fejlődés jegyében jövőbeni hasznosításra vonatkozó irányelveket meghatározni.

$\mathrm{A} \mathrm{Z}_{31}$ és $\mathrm{Z}_{32}$ mezóben (sárgával kiemelve) találhatók azok a helyszínek, amelyek magas tudományos értékkel bírnak, azonban a hozzáadott érték pontszáma kevés, ezért jövőbeli infrastrukturális fejlesztés színhelyei lehetnek. Ez elsősorban információs táblák kihelyezését, területrendezést, nagyobb fokú népszerúsítést, esetleg tanösvény létesítést jelent. 
A $Z_{22}$ cella helyszínei közül már csak a magasabb pontszámmal rendelkezők bírnak figyelemre méltó potenciállal. A többi mező esetében a rövid távú fejlesztés nem javasolt. Erre csak a terület aktív geoturisztikai vérkeringésbe való bekapcsolódása révén kerülhet sor, amikor anyagi forrás és társadalmi igény is mutatkozik a fejlesztésre.

\section{Az adatok klaszterezése a természetes törések módszerének felhasználásával}

Az előzőekben leírt mátrixban (3.ábra) látható, hogy a helyszínek nagyobb része a legjobb értékeket hordozó mezőkön kívül esik. Fontos a legmagasabb pontszámmal rendelkező geotópok leválogatása, hiszen ezek generálják a legnagyobb érdeklődést. Ennek tagjai a magasabb értékekkel bíró, valamint a $\mathrm{Z}_{22}$ cellákban foglalnak helyet.

A legkedvezőbb értékekkel bíró csoport megállapításához a JENKS, G. (1967) által leírt természetes törések (natural breaks) adatosztályozási módszert használtuk. A modell ezt a csoportok átlagos varianciájának (szórásnégyzetének) minimalizálásával és az osztályok közötti variancia maximalizálásával éri el. A QGIS segítségével választottuk két részre az adatsort. A kapott eredményt az előzőhöz hasonló diagramon és térképen ábrázolva jól elkülönülnek a magasabb pontszámmal bíró helyszínek (4-5. ábra; 3. táblázat).

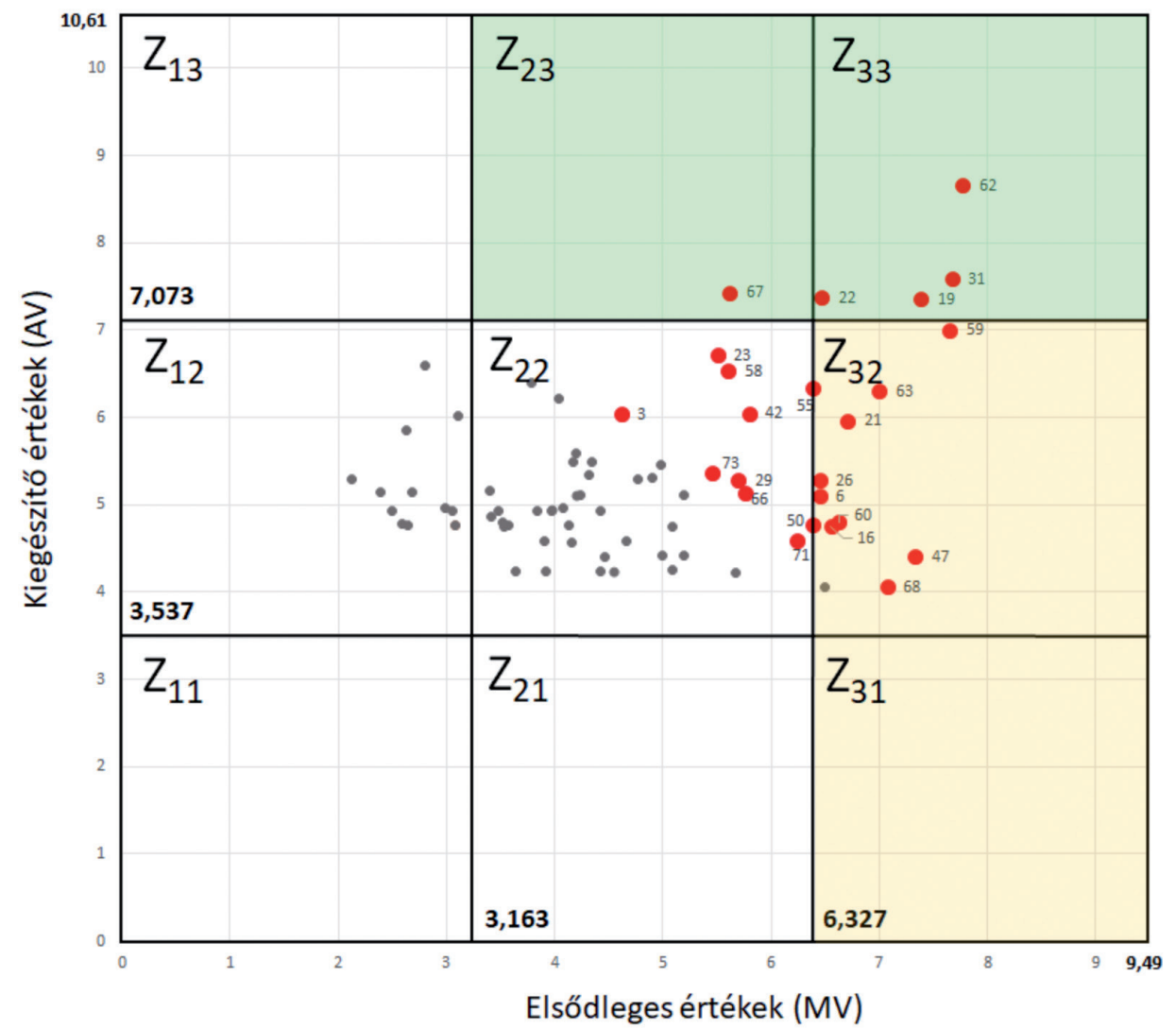

4. ábra A JENKS-féle optimalizáció (természetes törések) alkalmazása után kialakult adatcsoport (piros pontok)

Figure 4 The matrix after using JENKS' 'natural breaks' method. Red dots are the geosites with the highest point values 


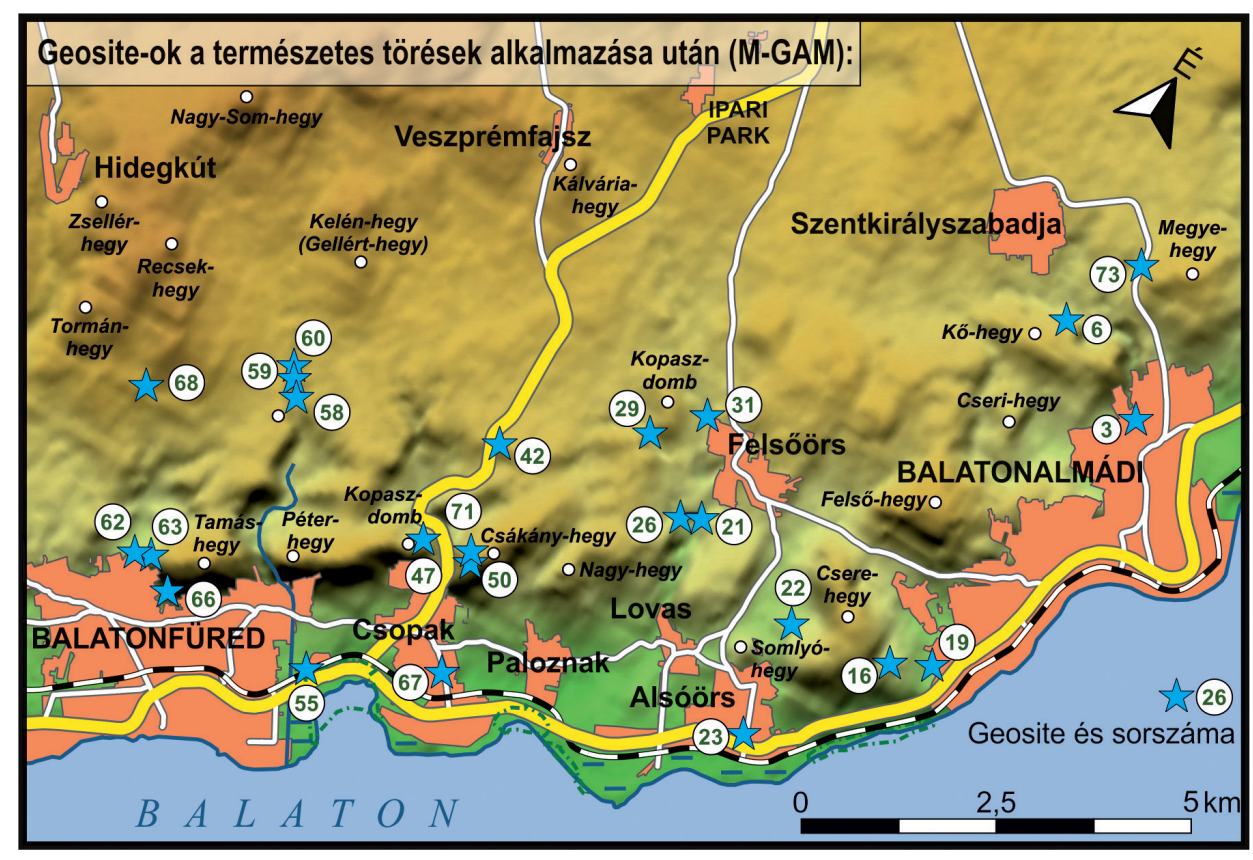

5. ábra A szelektált helyszínek térképe

Figure 5 Map of the clustered geosites

3. táblázat-Table 3

A leválogatott elemek nevei és M-GAM pontszámai

The clustered elements with M-GAM values

\begin{tabular}{|c|c|c|c|c|c|}
\hline ID & Név & Pontszám & ID & Név & Pontszám \\
\hline 62 & Lóczy-barlang, kőfejtő & 16,43 & 26 & $\begin{array}{l}\text { Miske-sziklával szemközti } \\
\text { feltárás }\end{array}$ & 11,74 \\
\hline 31 & Felsőörs, Forrás-hegyi tanösvény & 15,26 & 47 & Kopasz-domb, kőfejtő orma & 11,74 \\
\hline 19 & Köcsi-tavi tanösvény & 14,74 & 6 & Kő-hegy - Ember-szikla & 11,55 \\
\hline 59 & Koloska-sziklák & 14,65 & 60 & Koloska-hárs & 11,43 \\
\hline 22 & $\begin{array}{l}\text { Alsóörs, Vöröskő tanösvény, } \\
\text { amfiteátrum }\end{array}$ & 13,85 & 16 & Nagy-kő orra & 11,31 \\
\hline 63 & $\begin{array}{l}\text { Lóczy-barlang feletti } \\
\text { mészkősziklák }\end{array}$ & 13,30 & 50 & $\begin{array}{l}\text { Iszkahegyi Mészkősziklák } \\
\text { a Csákány-hegyi-barlangnál }\end{array}$ & 11,15 \\
\hline 67 & $\begin{array}{l}\text { Csopak, Nemzeti Park } \\
\text { Igazgatóság parkja, Pele-körút }\end{array}$ & 13,05 & 68 & Sárkány-lik & 11,14 \\
\hline 55 & $\begin{array}{l}\text { Csopak (Nádaskút), werfeni } \\
\text { alapszelvény }\end{array}$ & 12,71 & 29 & Király-kúti-völgy, mészkő & 10,97 \\
\hline 21 & Miske-szikla & 12,67 & 66 & $\begin{array}{l}\text { Tamás-hegy, dolomitos } \\
\text { üledékfal }\end{array}$ & 10,89 \\
\hline 23 & Alsóörsi metariolit, alapszelvény & 12,22 & 71 & Csákány-hegyi-barlang & 10,83 \\
\hline 58 & $\begin{array}{l}\text { Fődolomit feltárások } \\
\text { a Koloska-völgyben }\end{array}$ & 12,14 & 73 & $\begin{array}{l}\text { Balatonalmádi, } \\
\text { triász alapszelvény }\end{array}$ & 10,81 \\
\hline 42 & $\begin{array}{l}\text { Sándorhegyi és Fődolomit } \\
\text { Formációk alapszelvénye }\end{array}$ & 11,84 & 3 & $\begin{array}{l}\text { Balatonalmádi, } \\
\text { P/T alapszelvény }\end{array}$ & 10,66 \\
\hline
\end{tabular}


A két rendszer közötti különbség az Im súlytényezővel való szorzásnak köszönhetően a pontszámok nagyságából adódik. Mivel

$$
\text { Im } \leq 1,
$$

minden esetben, az $M$-GAM pontszámai többnyire kisebbek a $G A M$ pontszámainál. A két értékelési rendszer szerint számított pontok különbsége a $G A M$ által meghatározott diagramon érzékelhető (6.ábra).

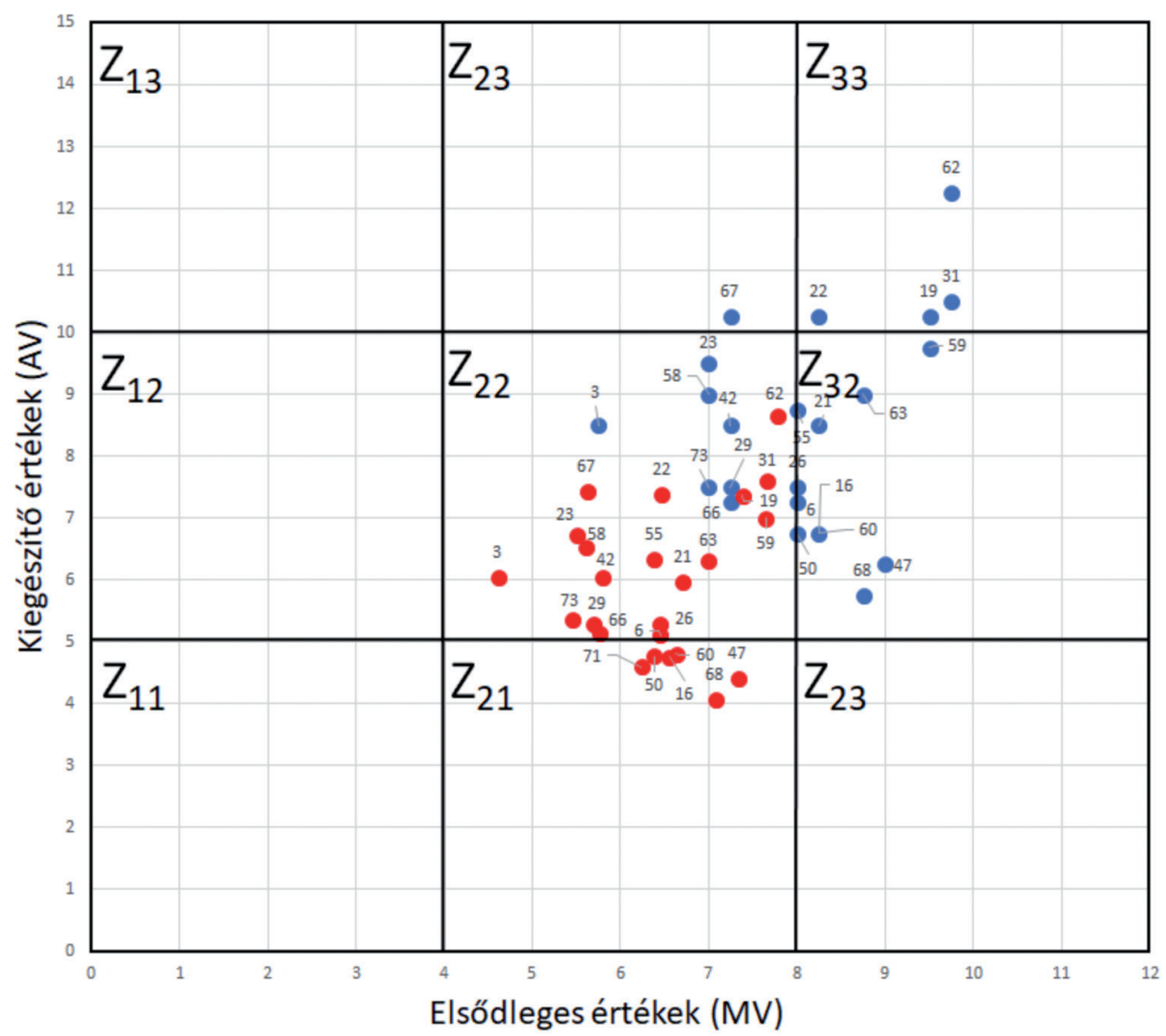

6. ábra A GAM és az $M$-GAM pontszámai a $G A M$ diagramjában ábrázolva. A pontok nevei a 3. táblázatban Figure 6 GAM and $M$-GAM values indicated in the GAM diagramme (Names of points see in Table 3)

Ezt követően minden geotóp két pontértéke között lefektettünk egy lineáris függvényt, amelyben a függvény változója az elsődleges, értéke pedig a hozzáadott érték volt. E függvények meredekségéből megállapítható, hogy az Im faktor az egyes helyszínek elsődleges vagy hozzáadott értékeire van nagyobb hatással. Ahogy 7. ábrán látszik, a kiválasztott 24 helyszín esetében kivétel nélkül 1-nél nagyobb a meredekség, tehát az $M$-GAM rendszerben a látogatók véleménye alapján meghatározott szorzó minden esetben nagyobb mértékben befolyásolja az infrastrukturális paramétereket ( $A V$-tengely). A mátrixban emiatt 


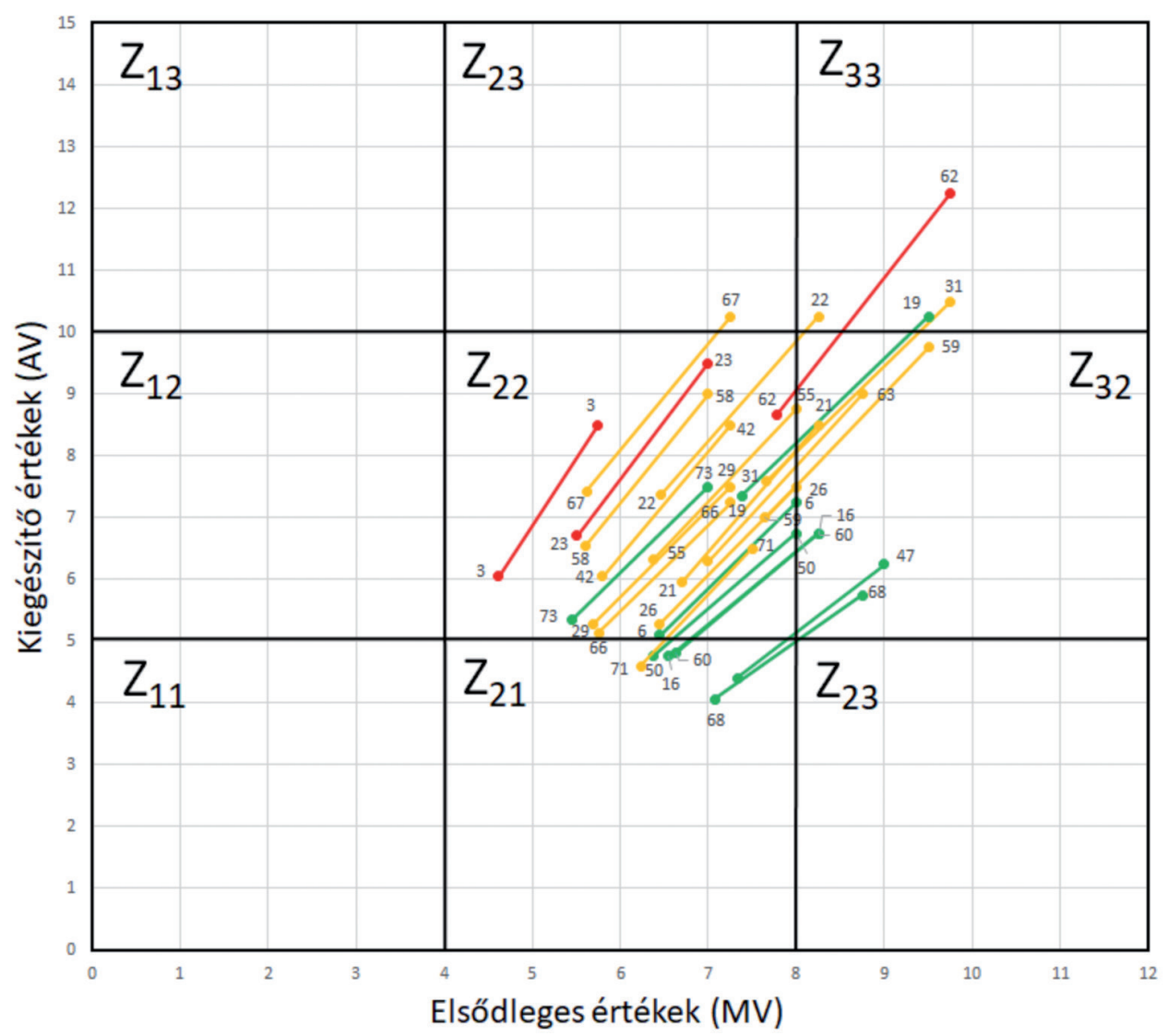

7. ábra A különböző meredekségú függvények ábrázolása

Figure 7 Linear functions with various slopes

három csoportra osztottuk a helyszíneket a függvénymeredekség alapján (a maximális és a minimális értékek különbségét egyenközűen felosztva) (4.táblázat).

4. táblázat-Table 4

A függvénymeredekségek táblázata

Slope values of the linear functions

\begin{tabular}{cccccccc}
\hline $\mathbf{I D}$ & $\mathbf{m}$ & $\mathbf{I D}$ & $\mathbf{m}$ & $\mathbf{I D}$ & $\mathbf{m}$ & $\mathbf{I D}$ & $\mathbf{m}$ \\
\hline $\mathbf{6 8}$ & 1,006 & $\mathbf{7 3}$ & 1,3829 & $\mathbf{5 9}$ & 1,4851 & $\mathbf{4 2}$ & 1,6856 \\
$\mathbf{4 7}$ & 1,1033 & $\mathbf{6}$ & 1,3833 & $\mathbf{5 5}$ & 1,4884 & $\mathbf{6 7}$ & 1,7259 \\
$\mathbf{1 6}$ & 1,1735 & $\mathbf{3 1}$ & 1,395 & $\mathbf{7 1}$ & 1,501 & $\mathbf{5 8}$ & 1,767 \\
$\mathbf{6 0}$ & 1,1988 & $\mathbf{6 6}$ & 1,4164 & $\mathbf{6 3}$ & 1,5429 & $\mathbf{6 2}$ & 1,8154 \\
$\mathbf{5 0}$ & 1,2188 & $\mathbf{2 6}$ & 1,4274 & $\mathbf{2 2}$ & 1,6101 & $\mathbf{2 3}$ & 1,8645 \\
$\mathbf{1 9}$ & 1,3648 & $\mathbf{2 9}$ & 1,4293 & $\mathbf{2 1}$ & 1,6434 & 3 & 2,163 \\
\hline
\end{tabular}

Zöld: $1,006 \leq m(z) \leq 1,39167$; sárga: $1,39167 \leq m(s) \leq 1,77733$; piros: $1,77733 \leq m(p) \leq 2,163$ 
Az Im eltérő hatása szintén jól kifejezhető az egyes pontok $\Delta x(=\Delta M V)$ és $\Delta y(=\Delta A V)$ értékeinek összehasonlításával (8.ábra). A 7. ábra mátrixos ábrázolásához hasonlóan itt is leolvasható, hogy a pontszámokat alkotó két rész $(M V, A V)$ közül a hozzáadott értékek pontszámait módosítja inkább az Im szorzó. Leolvasható, hogy egy adott geotópot mennyivel inkább a jobb ellátottság miatt keres fel egy turista $(\triangle A V-\triangle M V)$. Kimutatható, hogy a leválogatott 24 pont mindegyikénél (még az egyik legkedvezőtlenebb helyen található Sárkány-lik [68] esetében is) ez az érték nagyobb, mint nulla.

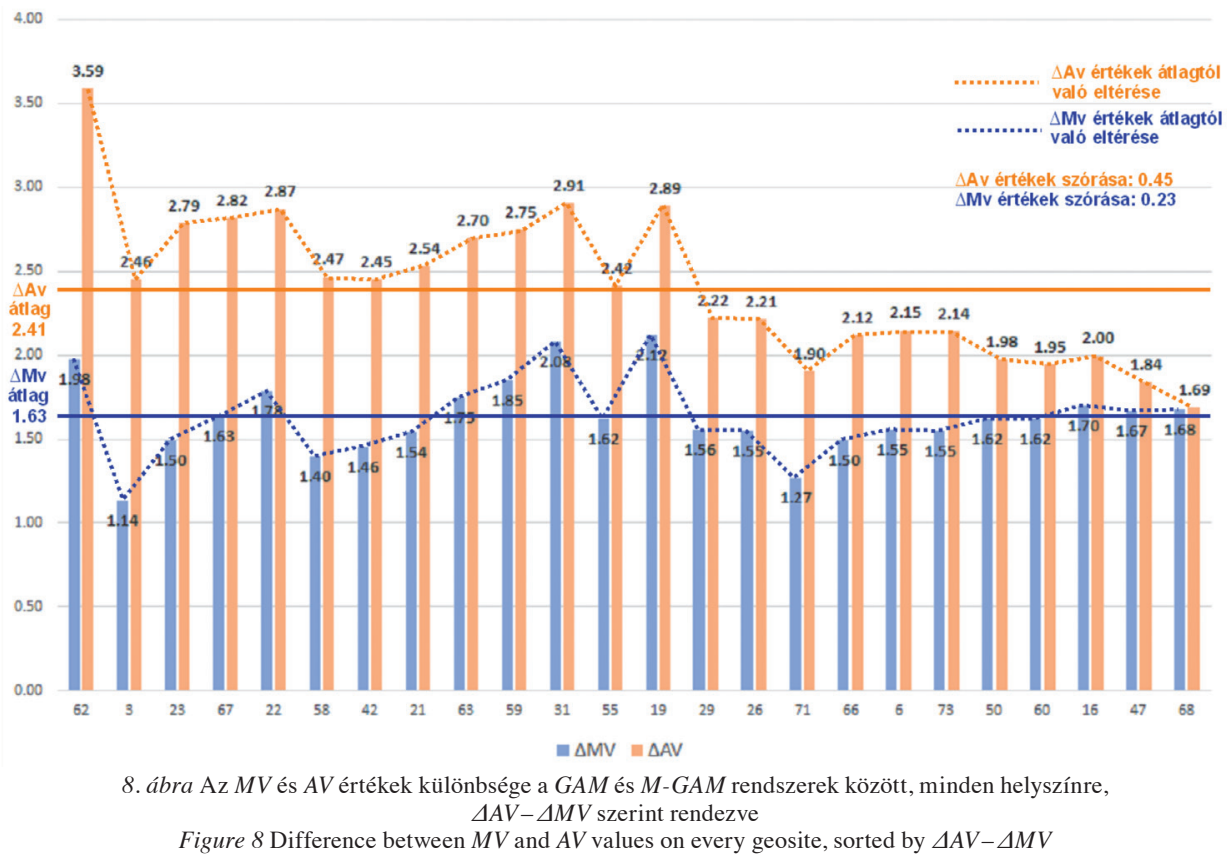

A fent vizsgált tényezőket figyelembe véve megállapítható, hogy egy átlagos geoturista nagyobb valószínúséggel látogat meg egy kevesebb tudományos-természetvédelmi értékekkel bíró geohelyszínt, ha az magasabb hozzáadott-infrastrukturális tényezőkkel bír. Ennek jelentősége abban rejlik, hogy a helyi közösségek és természetvédelmi szerveződések (esetünkben Balaton-felvidéki Nemzeti Park és Bakony-Balaton Geopark) elsődleges feladata azoknak a helyszíneknek a fejlesztése, amelyek $M V$ értékéhez képest az $A V$ kisebb, ennél fogva - a fentiek alapján - kevésbé vonzó.

\section{A Geopark elsố földtani túratérképe}

A kutatásban a $M$-GAM szerinti értékelés révén kiemelt 24 legjelentősebb geotópot a Bakony-Balaton Geopark vizsgált területéről készült földtani túratérképen is bemutattuk (ALBERT G. et al. 2018). A térkép topográfiai alapját SCHWARZ GY. (2013) szolgáltatta, földtani tematikáját pedig a térkép- és levéltárakban elérhető földtani térképek együttes feldolgozásából (MÂFI, 1980; BUDAI T. et al. 1999) nyerte (9. ábra).

A térkép méretaránya 1:30000, vágott mérete $700 \times 480 \mathrm{~mm}$, hajtogatott mérete $100 \times 160$ mm. Szerkesztői Albert G., PÁl M. és SchwarCz Gy., közremúködött Korbély 


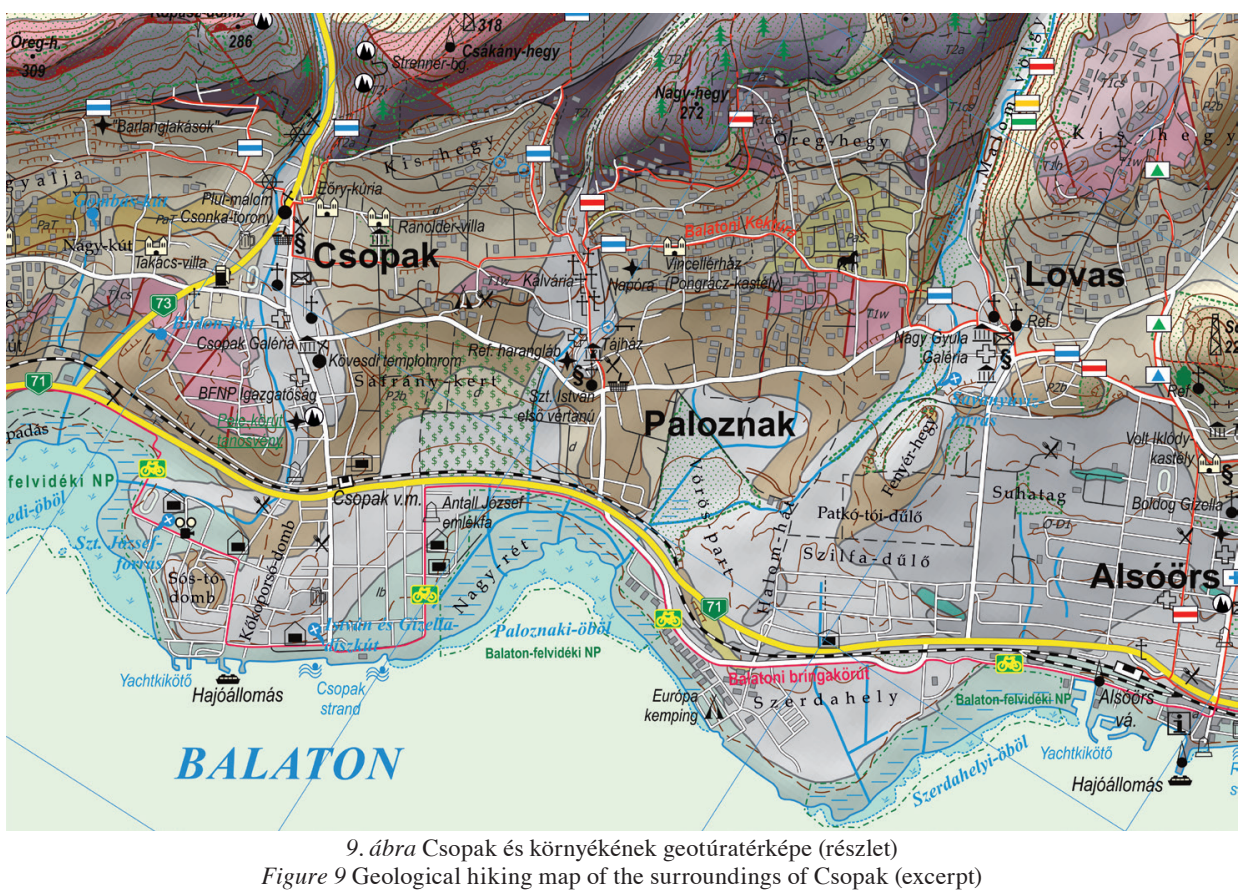

B. és BUDAI T. A térképoldalon helyet kap a terület rövid földtani leírása, a jelmagyarázat és a terület földtani keresztmetszete ÉNy-DK-i csapásirányban, amely ötvözi több évtizedes és jelenkori kutatómunkák eredményeit. Továbbá ugyanitt szerepel rövid leírás a területet kutató néhány neves földtudósnak (BöCKH J., LóCZY L. és CHOLNOKY J.) munkásságáról. A térkép hátoldalán található egy áttekintőtérkép-vázlat, a nevezetes geológiai bemutatóhelyek részletes ismertetése fényképpel és ábrákkal, valamint a többi geotóp felsorolása. A térkép első helyezést ért el az Országos Széchényi Könyvtár és az ELTE Térképtudományi és Geoinformatikai Tanszéke által meghirdetett Szép Magyar Térkép 2018 versenyen.

\section{Összefoglalás}

Munkánk során bebizonyosodott, hogy a Modified Geosite Assessment Model elődjéhez $(G A M)$ hasonlóan jól alkalmazható a magyarországi földtani bemutatóhelyek osztályozásához, sőt a látogatók bevonásával való objektivitásra törekvés miatt előnyösebb eredményeket kaphatunk használatával. Az értékelés a helyszíni tapasztalatokkal összevetve reális eredményeket hozott: az osztályozásban jó vagy kimagasló értékelést kapó helyszínek valóban népszerúek a látogatók körében. A Bakony-Balaton UNESCO Globális Geopark további területét feldolgozó geotúra-térképek készítésekor ugyancsak ezeket a módszereket tervezzük alkalmazni.

A két rendszer összehasonlítása lehetőséget hordoz magában arra, hogy a geotóp-fejlesztések iránya pontosan meghatározható legyen. A kutatás során először történt meg a GAM és $M$-GAM rendszerek ilyen mérvü összevetése, ami a két érték közti lineáris függvény elemzésével valósult meg. Ez egyrészt amiatt tekinthető csak közelító értéknek, mert az Im faktor számítása más területen történt, másrészt mert a bevont 96 turista által adott 
értéknek csak az átlagát vették. Szintén ezen a területen végzett felméréseink igazolták, hogy az Im értéke helyszínenként és egyénenként is más, ha nem általánosságban, hanem az adott helyszínre vonatkozóan kérdezzük a kitöltőket (PÁL, M.-AlBerT, G. 2019a). A helyszínenként végzett folyamatos adatgyújtéssel és azok statisztikai kiértékelésével (nem csak átlag, de szórás és trend) tartjuk lehetségesnek a célzott geoturisztikai fejlesztések gazdaságos tervezését és fenntartható kezelését.

Mivel tökéletesen kidolgozott és minden területre hiba nélkül alkalmazható rendszer valószínúleg nem létezik, folyamatos munka folyik a geoturizmus múvelői körében ezek pontosítása céljából. Munkánk során több mint 400 helyszínt ismertünk meg, amelyek közül 75-re a GAM és $M$-GAM modelleket alkalmazva szembesültünk módszerek hiányosságaival. Kiemelendő, hogy például nem számolnak az egyes helyszínek lehetséges veszélyeivel (forgalmas autóút, szélsőséges terepviszonyok), valamint bizonyos paraméterek esetében túl megengedőek (utak, szállás, éttermek közelsége - ez nyilván területfüggő, de Magyarországon nagyon elszigetelt helyszín nagyon kevés található). Ezek miatt a jövőben pontosabb értékelést és elemzést lehetôvé tevő modell kidolgozását is lehetségesnek tartjuk, aminek során a természetjárók bevonása és egyéb internetes lehetôségek használata (pl. Google Helyi idegenvezetők) is lehetséges.

Eredményeink kommunikálása a nagyközönség felé a fenntartható turizmus és geooktatás szélesebb körben való terjesztése miatt különösen fontos. E célt szolgálja a kiadott geotúra-térkép, valamint egyéb információs platformok fejlesztése (1. pl. PÁL, M.-ALBERT, G. 2019b). Megfelelő kommunikációval a geoturizmus elindíthat olyan folyamatokat, amelyek előrelépést jelenthetnek a nehezebb sorsú, természeti szempontból viszont értékes területek számára. Hangsúlyozzuk a felmért geoturisztikai potenciál fontosságát: egy terület kiépítése során számításba kell venni és értékelni kell a rendelkezésünkre álló lehetőségeket, az ezekre felmerülő igényt és az ez irányú ellátottságot. A felmérésekkel súlyos hibákat - fölösleges, beruházásokat vagy a turistákat hidegen hagyó fejlesztéseket - kerülhetünk el.

\section{PÁl MÁRton}

ELTE Térképtudományi és Geoinformatikai Tanszék, Budapest marchello@map.elte.hu

\section{ALBERT GÁsPÁr}

ELTE Térképtudományi és Geoinformatikai Tanszék, Budapest

albert@ludens.elte.hu

\section{IRODALOM}

Alavi, J.-Yasin, M. 2000: Iran's Tourism Potential and Market Realities: An Empirical Approach to Closing the Gap. - Journal of Travel and Tourism Marketing 9. 3. pp. 21-22.

ALBERT G. 2004: Földtudományok eredménye „kézzelfoghatóan”: a földtani túratérkép.-Geodézia és Kartográfia 51. 7. pp. 27-30.

Albert G.-PÁL M.-Schwarcz Gy. 2018: Csopak és környéke geotúratérképe. - Schwarcz Térkép, Tök.

Bakony-Balaton Geopark 2012: Mi a geopark? - Forrás: http://geopark.hu/home/mi-a-geopark

BRILHA, J. 2015: Inventory and Quantitative Assessment of Geosites and Geodiversity Sites: a Review. - Geoheritage 8. pp. 119-134.

Brilha, J.-Gray, M.-Pereira, D.-Pereira, P. 2018: Geodiversity: An integrative review as a contribution to the sustainable management of the whole of nature. - Environmental Science and Policy 86. pp. 19-28.

BRILHA, J. 2018: Geoheritage: Inventories and Evaluation. - In: REYNARD, E.-BRILHA, J. (eds): Geoheritage. - Elsevier. pp. 69-85. https://doi.org/10.1016/B978-0-12-809531-7.00004-6

Budai T. - KonRÁD Gy. 2011: Magyarország földtana (egyetemi jegyzet). - Pécsi Tudományegyetem, Természettudományi Kar, Pécs. 
Budai T.-Csillag G.-DudKo A.-KoloszÁr L. 1999: A Balaton-felvidék földtani térképe.- Magyar Állami Földtani Intézet, Budapest.

CSÁSZÁR, G. 1997: Lithostratigraphic chart of the Hungarian Stratigraphic Commission. - Magyar Állami Földtani Intézet, Budapest.

CsORvÁsı N. 2017: Geoturisztikai potenciálfelmérés Fejér megyei mintaterületeken. - XXXIII. OTDK Fizika, Földtudományok, Matematika Szekció, Debrecen.

DowLING, R. 2011: Geotourism's Global Growth. - Geoheritage 3. 1. pp. 1-13.

Futó J. 2013: Túrajavaslatok - A természet élménye a Balaton mellékén és a Bakonyban. - Balaton-felvidéki Nemzeti Park Igazgatóság, Csopak.

Gálosi K. B.-HoRVÁTH G. 2018: Határokon átnyúló természetvédelmi területek lehetőségei és problémái. - Földrajzi Közlemények 142. 4. pp. 309-327.

GócZÁn, L.-KERTÉSZ, Á. 1988: Some results of soil erosion monitoring at a large-scale farming experimental station in Hungary. - Catena Supplement 12. pp. 175-184.

Grant, C. 2010: Towards a typology of visitors to geosites. - Second Global Geotourism Conference, Making Unique Landforms Understandable. Mulu, Sarawak, Malajzia.

Hall, C.-PAGE, S. 2002: The Geography of Tourism and Recreation. - Routledge, London.

Hose, T. A. 1996: Geotourism, or can tourists become casual rock hounds? - In: BenNETT, M. R.-DoYLE, P. (eds.): Geology on your doorstep. The Geological Society, London. 207-228.

JAFARI, J. 2000: Encyclopedia of Tourism. - Routledge, London.

JEnKs, G. 1967: The Data Model Concept in Statistical Mapping. - International Yearbook of Cartography 7. pp. 186-190.

LAI, L.-GRAEFE, A. 2000: Identifying Market Potential and Destination Choice Factors of Taiwanese Overseas Travelers. - Journal of Hospitality \& Leisure Marketing 6. 4. pp. 45-65.

MÁFI 1980: A Balaton környékének 1: 20 000-es építésföldtani térképe. - Magyar Állami Földtani Intézet, Budapest.

Magyarhoni Földtani Társulat 2017: Geotóp Nap. - Forrás: http://geotopnap.hu/

MBFSZ 2017: Magyarország földtani alapszelvényei. - Forrás: https://map.mbfsz.gov.hu/fdt_alapszelvenyek/

Michalkó G. 2005: Turizmusföldrajz és humánökológia. - MTA Földrajztudományi Kutatóintézet, Budapest.

Newsome, D.-Dowling, R. 2010: Geotourism: The Tourism of Geology and Landscape. - Goodfellow Publishers.

PÁl, M.-AlBert, G. 2019a: Managing the spatial variability of geosite assessment in the Balaton Uplands (Hungary). - Geophysical Research Abstracts, vol. 21. EGU2019-545.

PÁL, M.-Albert, G. 2019b: Digital cartography for geoheritage: turning an analogue geotourist map into digital. - Proc. Int. Cartogr. Assoc. 2. 96. https://doi.org/10.5194/ica-proc-2-96-2019, 2019.

REYNARD, E. 2008: Scientific research and tourist promotion of geomoprhological heritage. - Geografia Fisica e Dinamica Quaternaria 31. pp. 225-230.

Schwarcz Gy. 2013: Felsőörs és környéke, 1:35000. - Schwarcz Térkép, Tök.

Stueve, A. M.-Cook, S. D.-Drew, D. 2002: The Geotourism study: phase 1 executive summary, Washington, D. C. - Travel Industry Association of America.

SzEPESI J.-Ésik Zs.-Soós I.-NovÁK T.-SÜTő L.-RózSA P.-LuKÁCs R.-HARANGi Sz. 2018: Földtani objektumok értékminősítése: módszertani értékelés a védelem, bemutatás, fenntarthatóság és a geoturisztikai fejlesztések tükrében. - Földtani Közlöny 148.pp. 143-160.https://doi.org/10.23928/foldt.kozl.2018.148.2.143.

SzEPESI, J.-HARANGI, Sz.-Ésik, Zs.-NovÁk, T.-LuKÁcs, R.-Soós, I. 2016: Volcanic Geoheritage and Geotourism Perspectives in Hungary: a Case of an UNESCO World Heritage Site, Tokaj Wine Region Historic Cultural Landscape, Hungary. - Geoheritage 9. 3.. pp. 329-349.

Tomić, N.-Božić, S. 2014: A modified Geosite Assessment Model (M-GAM) and its Application on the Lazar Canyon area (Serbia). - International Journal of Environmental Research 8.4. pp. 1041-1052.

Tóth Sz.-PinTÉR Z.-LÁNCZi D.-HoRVÁTH G. 2015: Különleges felszínalaktani egyedi tájértékek: a nagybárkányi hegyi tavak. - Földrajzi Közlemények 139. 1. pp. 14-29.

Vujičić, M.- Vasiljević, D.-Marković, S.-Hose, T.-Lukić, T.-HadžIć, O.-Janićević, S. 2011: Preliminary Geosite Assessment Model (GAM) and its application on Fruška Gora mountain, potential geotourism destination of Serbia. - Acta Geographica Slovenica 51. 2. pp. 361-377. 